\title{
Aloe Vera (Aloe barbadensis) as Feed Additive for Buffalo Calves: Effects on Gut Parasites and Cost of Production
}

\author{
Ravinder Saini $^{*}$, Suresh K Chhikara ${ }^{1}$, Subhasish Sahu ${ }^{1}$, Dipin Chander Yadav ${ }^{1}$ and Pradeep Kumar $^{2}$ \\ ${ }^{1}$ Department of Livestock Production Management, Lala Lajpat Rai University of Veterinary and Animal Sciences, \\ Hisar, Haryana, INDIA \\ ${ }^{2}$ Department of Veterinary Parasitology, Lala Lajpat Rai University of Veterinary and Animal Sciences, Hisar, Haryana, INDIA \\ "Corresponding author: R Saini; E-mail: sainiravi6@gmail.com
}

Received: 30 May, 2021

Revised: 19 July, 2021

Accepted: 22 July, 2021

\begin{abstract}
The aim of this work was to compare the efficacy of two different doses of aloe vera (Aloe barbadensis) supplementation on gut parasites and cost of production in Murrah buffalo calves. A total of fifteen buffalo calves (3-6 months age) were selected and maintained at the Buffalo Farm, Department of Livestock Production Management, College of Veterinary Sciences, LUVAS, Hisar (Haryana), India. The duration of experiment was 90 days. The calves were placed into three treatment groups $\mathrm{T}_{1}, \mathrm{~T}_{2}$ and $\mathrm{T}_{3}$ (based on nearness in body weight and age) and each group having five calves. The calves were fed with basal ration in all three treatment groups according to ICAR-2013 feeding standards along with supplementation of aloe vera leaves @ $2 \mathrm{~g}$ and $4 \mathrm{~g}$ per kg body weight in $\mathrm{T}_{2}$ and $\mathrm{T}_{3}$ group respectively. The calves fed basal diet supplemented with aloe vera @ $4 \mathrm{~g}$ per kg body weight were showed significantly lower $(\mathrm{P}<0.05)$ oocyst per gram (opg) and also showed less egg per gram (epg) but not significantly $(\mathrm{P}>0.05)$, in faeces as compare to control group. The cost of feeding per kg body weight gain was found lowest in $\mathrm{T}_{3}$ followed by $\mathrm{T}_{2}$ and was found highest in $\mathrm{T}_{1}$ treatment group Thus, from above findings it can be concluded that aloe vera supplementation@ @ $\mathrm{g} / \mathrm{kg}$ body weight can be an effective herbal feed additive for buffalo calves and can increase the economic return to the farmers.
\end{abstract}

\section{HIGHLIGHTS}

(0 Aloe vera has substantial effect on gut parasites.

(0 The feeding cost $/ \mathrm{kg}$ weight gain was found lowest in calves fed diet supplemented with aloe vera @ $4 \mathrm{~g} / \mathrm{kg}$ body weight.

Keywords: Aloe vera, Calves, Egg per gram, Gut parasites, Oocyst per gram

India ranks first in the world in milk production, which went up from 17 million tonnes in $1950-51$ to 198.4 million tonnes in 2019-20 (Economic Survey, 202021 ) and $49 \%$ of milk in India is produced by buffaloes. Approximately $63 \%$ of the world's total buffalo milk and $95 \%$ of buffalo milk produced in Asia is contributed by Indian buffaloes (Anonymous, 2012). The calves form the future herd (Kumar et al., 2017) and economic return can be optimized by reducing calf mortality and adopting better management and husbandry practices. The major approximately $30 \%$ mortality in calf is recorded due to gastrointestinal infection (Nehru et al., 2017). The excessive or repetitive prophylactic use of drugs against gastrointestinal problems is not only costly but also renders animals prone to development of drug resistance; it prompted researchers to look for alternative of drugs to control the disease and a number of medicinal plants have been identified for their use as herbal feed additive including aloe vera which in turn may improve the performance of livestock (Yadav et al., 2017a). Aloe barbadensis (aloe

How to cite this article: Saini, R., Chhikara, S.K., Sahu, S., Yadav, D.C and Kumar, P. (2021). Aloe Vera (Aloe barbadensis) as Feed Additive for Buffalo Calves: Effects on Gut Parasites and Cost of Production. J. Anim. Res., 11(04): 675-679.

Source of Support: None; Conflict of Interest: None क क 
vera) belongs to Liliaceae family and its leaves have several medicinal and therapeutic properties (Qiao et al., 2013). Aloe vera gel has been known as health promoter due to number of medicinal properties like immunomodulatory, anti-inflammatory, antiviral, antifungal, antitumor, antimicrobial, wound healing, antidiabetic and antioxidant properties (Sharma et al., 2014; Maan et al., 2018), because of its chemical components, including minerals, proteins, enzymes, carbohydrates, vitamins, saponins and anthraquinones (Giannakoudakis et al., 2018). As the use of ethnoveterinary medicines plays an important role in curbing the problem of drug resistance. Aloe vera could prove be a better option to replace antiparasitic drugs. Keeping in view this hypothesis, the present study was planned with objectives to estimate antiparasitic activity and cost effectiveness of different doses of aloe vera.

\section{MATERIALS AND METHODS}

The experiment was conducted at Buffalo farm, Department of Livestock Production Management, College of Veterinary Sciences, LUVAS, Hisar (Haryana) for 90 days. Prior approval was taken to conduct the present investigation by the Institutional Animal Ethics Committee (vide memo no. VCC/IAEC/1745-1775 dated: 29/12/2020). Fifteen Murrah buffalo calves (3-6 months) of either sex were selected. These buffalo calves were divided into three equal groups consisting of five calves in each group based on uniform body weight and age (Table 1) and subjected to following stall feeding treatments under similar housing and managemental facilities i.e. $\mathrm{T}_{1}$ (Basal diet- Control) $\mathrm{T}_{2}$ (Basal diet + aloe vera leaves@ 2 g/kg BW) and $\mathrm{T}_{3}$ (Basal diet+ aloe vera leaves @ 4g/kg $\mathrm{BW})$. All the buffalo calves were dewormed during the preliminary adjustment period of seven days before the start of experiment and thereafter no dewormer was given even to control group so as to analyse the antiparasitic activities of aloe vera. The different feed stuffs (berseem, wheat straw and concentrate mixture) were offered to all the calves during stall feeding so that their protein and energy requirement can be met as per feeding standards specified by the ICAR (2013). The animals were also offered with drinking water on adlib basis throughout the day. The experimental calves were weighed individually at the start of the experiment and at fortnightly intervals thereafter, in morning hours before feeding and watering on digital weighing balance and body weights were utilized for computation of ration and cost of feeding per $\mathrm{kg}$ weight gain. Before formulations of the basal ration for all buffalo calves, the different feed ingredients along with fresh aloe vera leaves were analyzed (AOAC, 2013) for proximate composition and based on analysis concentrate mixture was formulated (Table 2). Aloe vera was procured from Medicinal and Aromatic Plant Section, Department of Plant Breeding, College of Agriculture, CCS HAU, Hisar on daily basis. The fresh aloe vera leaves were grinded in the electric mixer to prepare the crude extract so that easily fed to the animals along with concentrate.

Table 1: Distribution of experimental buffalo calves under different dietary treatments

\begin{tabular}{llll}
\hline Treatment & $\begin{array}{l}\text { No. of } \\
\text { Calves }\end{array}$ & $\begin{array}{l}\text { Average Body } \\
\text { Weight }(\mathbf{k g})\end{array}$ & $\begin{array}{l}\text { Average Age (in } \\
\text { days) }\end{array}$ \\
\hline $\mathrm{T}_{1}$ & 5 & 72.2 & 123.4 \\
$\mathrm{~T}_{2}$ & 5 & 73.4 & 121 \\
$\mathrm{~T}_{3}$ & 5 & 72.8 & 119.6 \\
\hline
\end{tabular}

Table 2: Proximate composition (\% DM Basis) of concentrate mixture

\begin{tabular}{llllllll}
\hline Ingredients & DM & CP & CF & EE & Ash & OM & NFE \\
\hline $\begin{array}{l}\text { Concentrate } \\
\text { mixture }\end{array}$ & 90.00 & 20.0 & 10.14 & 2.8 & 6.97 & 93.03 & 60.09 \\
\hline
\end{tabular}

The fresh faecal samples were collected during early morning hours directly from the rectum from all the fifteen animals belonging to the three experimental groups at the beginning of the experiment and thereafter at monthly interval. The samples were collected and then examined for estimation of egg per gram (epg) for nematodes and oocyst per gram (opg) by using Modified McMaster's technique at laboratory of Department of Veterinary Parasitology, LUVAS, Hisar. Count the total number of eggs and oocyst in the chamber and multiplied the count by 100 to get egg per gram (epg) and oocyst per gram (opg).

The feed intake by buffalo calves during the experiment was determined on the basis of weighing of feed and fodder offered and the left over for two consecutive days at fortnightly interval. Prices of feed ingredients (including price of dry fodder, green fodder, aloe vera and concentrate mixture), prevailing at the time of purchase were collected from the Department of Animal Nutrition of the University and for aloe vera from MAP section of CCSHAU, Hisar. 
On the basis of these prices, total expenditure incurred on feeding of various treatment groups during the experiment period was calculated. Cost of feeding per $\mathrm{kg}$ body weight gain was also computed for different treatment groups by dividing cost of rearing of calves in each group from average weight gain of respective groups.

All the data were analyzed statistically by using SPSS, $20^{\text {th }}$ Version software as per Snedecor and Cochran (1994) and comparison of means was done by calculating one way analysis of variance (ANOVA), using Duncan's multiple range tests (Duncan, 1955).

\section{RESULTS AND DISCUSSION}

\section{Oocyst per gram in faeces (opg)}

The mean opg in faeces of Murrah buffalo calves of all treatment groups has been presented in Table 3. There was low oocyst forming parasites load in all the groups in the beginning of experiment however significant results $(\mathrm{P}<0.05)$ were observed after administration of aloe vera (a) $4 \mathrm{~g} / \mathrm{kg}$ body weight in calves of treatment group $\mathrm{T}_{3}$ as compare to control and lower aloe vera supplemented group $\mathrm{T}_{2}$ on day $90^{\text {th }}$ of experiment. At the end of experiment opg count was found lowest in treatment group $\mathrm{T}_{3}$ followed by treatment group $\mathrm{T}_{2}$ and was found highest in control group $T_{1}$. The scientific literature similar to this experimental protocol is very scanty but supported experiments are discussed as follows. The results of present experiment are in agreement with the findings of Maphosa and Masika (2012) who observed reduction in Eimeria species oocyst on aloe vera supplementation in goats as compared to control. Akhtar et al. (2012) also found that fecal oocyst shedding in broilers was significantly lower $(\mathrm{P}<0.05)$ compared to the infected control group on aloe vera supplementation. This reduction in coccidian oocysts might be due to antioxidant property of aloe vera which may reduce the severity of infection (Kaingu et al., 2017). Researchers in the recent past are in agreement that aloe vera has active compounds including beta-carotene, vitamin $\mathrm{C}$ and $\mathrm{E}$, vitamin $\mathrm{B} 12$, folic acid, choline, glucomannans, acemannans, proteins and minerals, which effectively control multiplication of oocysts in the intestines and caeca (Ahmad et al., 2020).

\section{Egg per gram in faeces (epg)}

The mean value of faecal egg count per gram of nematodes (mainly Strongyles) at the end of experiment were observed with decreasing trend from 580 in $\mathrm{T}_{1}$ control group to 400 in $\mathrm{T}_{2}$ (Aloe vera @ $2 \mathrm{~g} / \mathrm{kg}$ body weight) and then 320 in $\mathrm{T}_{3}$ (Aloe vera @ 2g/kg body weight) treatment groups, however the epg count did not differ significantly $(\mathrm{P}>0.05)$ between different treatment group (Table 4).

Table 3: Mean total oocyst per gram (opg) in faeces of buffalo calves at monthly interval

\begin{tabular}{llll}
\hline \multirow{2}{*}{ Months } & \multicolumn{3}{c}{ Treatments } \\
\cline { 2 - 4 } $\mathbf{T}_{\mathbf{1}}$ & $\mathbf{T}_{\mathbf{2}}$ & $\mathbf{T}_{\mathbf{3}}$ \\
\hline Initial & $80.00 \pm 37.42$ & $80.00 \pm 16.61$ & $100.00 \pm 31.62$ \\
I & $180.00 \pm 37.42$ & $200.00 \pm 44.72$ & $160.00 \pm 24.49$ \\
II & $360.00 \pm 40.00$ & $340.00 \pm 60.00$ & $300.00 \pm 44.72$ \\
III & $740.00 \pm 60.00^{\mathrm{b}}$ & $480.00 \pm 66.33^{\mathrm{b}}$ & $440.00 \pm 87.18^{\mathrm{a}}$ \\
\hline
\end{tabular}

a,b Mean values with different superscripts in a row differ significantly at ' $P<0.05$ '.

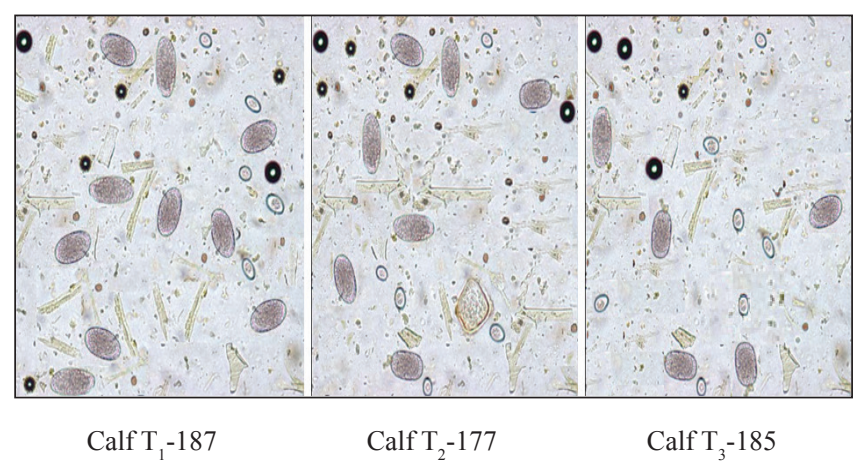

Fig. 1: Microscopic images of eggs and oocysts in faeces of calves from each treatment group

The results of present experiment are in agreement with the findings of Yadav et al. (2017b) who observed lower epg count in aloe vera treated groups as compare to control, however no significant difference was observed in internal parasitic load on aloe vera supplementation in calves as compare to control. Ahmed et al. (2017) also observed that aloe vera supplementation in sheep did not show significant difference in gut parasitic load. The reduction of egg count in aloe vera supplemented groups might be due to activity of flavonoids and phenolic compounds present in aloe vera (Shelke et al., 2020). It may also due 
to better growth and greater length of villi along with rapid clearance of villi in aloe vera supplemented groups. However the regular deworming schedule was practiced at the farm before the start of experiment and animals were stall fed during the experiment but still they got infected with parasitic infection which might be due to feeding of green fodder during the experiment which is supposed to be potent source of parasitic infection.

Table 4: Mean total nematodal eggs per gram (opg) in faeces of buffalo calves at monthly interval

\begin{tabular}{llll}
\hline \multirow{2}{*}{ Months } & \multicolumn{3}{c}{ Treatments } \\
\cline { 2 - 4 } & $\mathbf{T}_{\mathbf{1}}$ & $\mathbf{T}_{\mathbf{2}}$ & $\mathbf{T}_{\mathbf{3}}$ \\
\hline Initial & $0.00 \pm 0.00$ & $0.00 \pm 0.00$ & $0.00 \pm 0.00$ \\
I & $60.00 \pm 40.00$ & $40.00 \pm 24.49$ & $60.00 \pm 40.00$ \\
II & $200.00 \pm 63.25$ & $180.00 \pm 37.42$ & $160.00 \pm 40.00$ \\
III & $580.00 \pm 124.10$ & $400.00 \pm 94.97$ & $320.00 \pm 58.31$ \\
\hline
\end{tabular}

Values are means \pm standard errors.

\section{Economics of feeding}

The economics of feeding of Murrah buffalo calves under different dietary treatments has been presented in Table 5. The total cost of feeding of buffalo calves for a period of 90 days was ₹ 16092.54, 17122.06 and 17922.36 in treatments $\mathrm{T}_{1}, \mathrm{~T}_{2}$ and $\mathrm{T}_{3}$ respectively.

Table 5: Total cost of feeding (₹) and cost of feeding per kg weight gain for experimental period

\begin{tabular}{llll}
\hline Variables & $\mathbf{T}_{\mathbf{1}}$ & $\mathbf{T}_{\mathbf{2}}$ & $\mathbf{T}_{\mathbf{3}}$ \\
\hline Concentrate mixture & & & \\
\hline Concentrate fed (quintal) & 5.25 & 5.25 & 5.31 \\
Concentrate price/quintal (₹) & 2202 & 2202 & 2202 \\
Cost of concentrate fed (₹) & 11560.5 & 11560.5 & 11692.62 \\
\hline Green fodder & & & \\
\hline Berseem fed (quintal) & 25.29 & 28.84 & 30.35 \\
Berseem price/quintal (₹) & 150 & 150 & 150 \\
Cost of berseem fed (₹) & 3793.50 & 4326.00 & 4552.50 \\
\hline Dry fodder & & & \\
\hline $\begin{array}{l}\text { Wheat straw fed (quintal) } \\
\text { Wheat straw price/quintal (₹) }\end{array}$ & 3.73 & 4.22 & 4.38 \\
$\begin{array}{l}\text { Cost of wheat straw fed (₹) } \\
738.54\end{array}$ & 835.56 & 867.24 \\
\hline
\end{tabular}

\begin{tabular}{|c|c|c|c|}
\hline \multicolumn{4}{|l|}{ Aloe vera } \\
\hline Aloe vera fed (quintal) & 0 & 0.80 & 1.62 \\
\hline Aloe vera price/quintal (₹) & 500 & 500 & 500 \\
\hline Cost of aloe vera fed (₹) & 0 & 400 & 810 \\
\hline \multicolumn{4}{|l|}{ Cost of feeding } \\
\hline Total Cost of feeding (₹) & 16092.54 & 17122.06 & 17922.36 \\
\hline Total body weight gain $(\mathrm{Kg})$ & 182 & 207 & 226 \\
\hline $\begin{array}{l}\text { Cost of feeding } / \mathrm{kg} \text { weight } \\
\text { gain (₹) }\end{array}$ & 88.42 & 82.72 & 79.30 \\
\hline
\end{tabular}

The feed cost calculated in terms of each $\mathrm{kg}$ body weight gain were $₹ 88.42,82.72$ and 79.30 in treatments $T_{1}, T_{2}$ and $\mathrm{T}_{3}$ respectively, which showed that feed cost per $\mathrm{kg}$ body weight gain decreased in treatment groups $\mathrm{T}_{2}$ and $\mathrm{T}_{3}$ in comparison to $T_{1}$ control group and was found lowest in $\mathrm{T}_{3}$ treatment i.e. it was most economical when expressed in term of cost per unit weight gain. Similar observations were recorded by Eevuri and Putturu (2013) who reported that the feed cost per unit weight gain reduced upon supplementation of aloe vera in broilers by 6.2 to $13.5 \%$. The economic benefit was found more in $\mathrm{T}_{3}$ treatment group as compare to $\mathrm{T}_{2}$ and $\mathrm{T}_{1}$ might be due to more weight gain in the higher aloe vera supplemented group.

\section{CONCLUSION}

Thus it can be concluded from the above discussion that inclusion of the aloe vera @ $4 \mathrm{~g}$ per kg body Weight in the diet of buffalo calves have substantial effect on control of gut parasites along with lower cost of feeding per $\mathrm{kg}$ weight gain as compare to control, so can use as herbal feed additive which in turn will increase the economic gain to the farmers.

\section{ACKNOWLEDGEMENTS}

The authors are thankful to the Vice Chancellor, Director of Research and Dean PGS, LUVAS, Hisar for providing necessary facilities and funds to carry out the research work.

\section{REFERENCES}

Ahmad, Z., Hafeez, A., Ullah, Q., Naz, S. and Khan, R.A. 2020. Protective effect of Aloe vera on growth performance, leucocyte count and intestinal injury in broiler chicken infected with coccidiosis. J. Appl. Anim. Res., 48(1): 252256. 
Ahmed, M., Basha, N.A., Laing, M.D. and Nsahlai, I.V. 2017. In vitro and in vivo effects of Aloe ferox extracts on gastrointestinal nematodes control and live weight gain of young sheep. HSOA J. Anim. Res. Vet. Sci., 1: 003.

Akhtar, M., Hai, A., Awais, M.M., Iqbal, Z., Muhammad, F., Haq, A.U. and Anwar, M.I. 2012. Immuno-stimulatory and protective effects of aloe vera against coccidiosis in industrial broiler chickens. Vet. Parasitol., 186: 170-177.

Anonymous. Govt. of India. 2012. $19^{\text {th }}$ Livestock census all India report. Ministry of Agriculture. Department of Animal Husbandary, Dairying and Fisheries, Krishibhavan, New Delhi.

Duncan, D.B. 1955. Multiple range and multiple F tests. Biometrics, 11(1): 1-42.

Economic Survey. 2019-2020. Agriculture and food management. Department of Economic Affairs, Government of India, New Delhi. Accessed 10 Apr., 2021.

Eevuri, T.R and Putturu, R. 2013. Use of certain herbal preparations in broiler feeds - A review. Vet. World, 6(3): 172-179.

Giannakoudakis, D.A., Hosseini-Bandegharaei, A., Tsafrakidou, P., Triantafyllidis, K.S., Kornaros, M. and Anastopoulos, I. 2018. Aloe vera waste biomass-based adsorbents for the removal of aquatic pollutants: a review. J. Environ. Manage., 227: 354-364.

ICAR. 2013. Nutrient Requirements of Animals- Cattle and Buffalo. $3^{\text {rd }}$ edn., Indian Council of Agricultural Research, Krishi Anusandhan Bhavan, Pusha, New Delhi.

Kaingu, F., Liu, D., Wang, L., Tao, J., Waihenya, R. and Kutima, H. 2017. Anticoccidial effects of Aloe secundiflora leaf extract against Eimeria tenella in broiler chicken. Trop. Anim. Health. Prod., 49(4): 823-828.

Kumar, R., Kumar, S., Palod, J., Tewari, H. and Singh, B. 2017. Effect of chedu and mattha on growth performance of Murrah buffalo calves. Indian J. Anim. Res., 51(5): 906-909.
Maan, A.A., Nazir, A., Khan, M.K.I., Ahmad, T., Zia, R., Murid, M. and Abrar, M. 2018. The therapeutic properties and applications of Aloe vera: a review. J. Herb. Med., 12: 1-10.

Maphosa, V. and Masika, P.J. 2012. In vivo validation of Aloe ferox (Mill). Elephantorrhiza elephantina Bruch. Skeels. and Leonotis leonurus (L) R. BR as potential anthelminthics and antiprotozoals against mixed infections of gastrointestinal nematodes in goats. Parasitol. Res., 110: 103-108.

Nehru, P.A., Sunandhadevi, S., Rama, T. and Muniyappan, N. 2017. Effect of probiotic supplementation on growth performance of crossbred calves in an organized cattle farm. J. Anim. Health Prod., 5(3): 89-91.

Qiao, J., Li, H.H., Zheng, Ch.J., Feng, Z.Y. and Wang, W. 2013. Dietary supplementation with aloe vera polysaccharide enhances the growth performance and immune function of weaned piglets. J. Anim. Feed Sci., 22: 329-334.

Sharma, P., Kharkwal, A.C., Kharkwal, H., Abdin, M.Z. and Varma, A. 2014. A review on pharmacological properties of Aloe vera. Int. J. Pharm. Sci. Rev. Res., 29(2): 31-37.

Shelke, P.S., Jagtap, P.N. and Tanpure, P.R. 2020. In-vitro anthelmintic activity of Boswellia serrata and Aloe barbadensis extracts on Pheretima posthuma: Indian earthworm. Int. J. Res. Med. Sci., 8(5): 1843-1847.

Snedecor, G.W. and Cochran, W.G. 1994. Statistical methods. $6^{\text {th }}$ edn., The Iowa State University Press, Ames, Iowa, USA.

Yadav, A.K., Kumar, S., Barman, R.S.D., Verma, R.K. and Jha, D.K. 2017a. The Effect of aloe vera on Growth and Body measurement traits in cross bred calf. Res. J. Chem. Environ. Sci., 5(4): 37-44.

Yadav, A.K., Kumar, S., Barman, R.S.D., Verma, R.K. and Jha, D.K. 2017b. The effect of aloe vera on feed intake efficiency and internal parasite load in cross bred calves. Int. J. Agric. Sci., 10(14): 6696-6699. 
